\title{
Competition between a native mussel and a non-indigenous invader for primary space on intertidal rocky shores in Chile
}

\author{
Andrés U. Caro ${ }^{1}$, Ricardo Guiñez ${ }^{2}$, Verónica Ortiz ${ }^{1}$, Juan Carlos Castilla ${ }^{1, *}$ \\ ${ }^{1}$ Center for Advanced Studies in Ecology and Biodiversity. Facultad de Ciencias Biológicas, \\ Pontificia Universidad Católica de Chile, Casilla 114-D, Santiago, Chile \\ ${ }^{2}$ Instituto de Investigaciones Oceanológicas, Facultad de Recursos del Mar, Universidad de Antofagasta, Casilla 170 , \\ Antofagasta, Chile
}

\begin{abstract}
Non-indigenous marine species have significant effects on rocky intertidal native biota and ecological processes. The tunicate Pyura praeputialis, a recent invader in the Bay of Antofagasta, Chile, has monopolized the low and mid-low rocky intertidal fringe and apparently constrained the native mussel Perumytilus purpuratus to the mid-upper fringe. We performed field experiments to determine interspecific competitive strengths and quantify survival and growth rates between these species at 2 intertidal heights: mid-low and mid-upper intertidal fringes. Our results showed that at the mid-low fringe $P$. praeputialis had greater competitive strength than $P$. purpuratus. In fact, the survival and growth rates of $P$. praeputialis were not significantly affected by the presence of $P$. purpuratus. Further, while the survival of $P$. purpuratus was not significantly affected by the presence of $P$. praeputialis, its growth rate was affected by the degree of encroachment by the tunicate. Mussels encroached by $P$. praeputialis grew significantly less than non-encroached ones. At the mid-upper intertidal fringe, the survival of $P$. praeputialis was significantly decreased by the presence of $P$. purpuratus: the tunicate is unable to grow at this intertidal fringe. At the low-intertidal fringe mussel growth rates were significantly greater than at the mid-upper fringe, while survival rates were similar. Our results support the hypothesis that in the Bay of Antofagasta the invading tunicate $P$. praeputialis is responsible for a major rocky intertidal ecological impact, outcompeting the native mussel from the mid-low fringe and thereby substantially modifying the zonation pattern.
\end{abstract}

KEY WORDS: Invasion · Pyura praeputialis $\cdot$ Perumytilus purpuratus $\cdot$ Tunicate $\cdot$ Rocky intertidal $\cdot$ Antofagasta Bay

Resale or republication not permitted without written consent of the publisher

\section{INTRODUCTION}

Biological invasions, defined as the arrival, establishment and subsequent spread of species beyond their historical range, have emerged as a major topic in ecology. Non-indigenous species (NIS) have significant effects on native biota, natural patterns and ecological processes through a variety of direct and indirect mechanisms occurring at genetic, individual, population, community and ecosystem scales (Griffiths et al.
1992, Lambert et al. 1992, Ruiz et al. 1997, 2000, Crooks 2002, Grosholz 2002, Olyarnik et al. 2009, Rilov $\&$ Crooks 2009). NIS can produce significant effects on local communities including changes in the species richness and local diversity (Fridley et al. 2007), the strength and direction of interspecific interactions (Holway et al. 2002, Eastwood et al. 2007) and the use of resources (Bubb et al. 2006). In many ecosystems, the success of NIS is facilitated by the absence of natural predators in the locality invaded, making the 
unchecked growth of the invasive population possible (Kolar \& Lodge 2001, 2002, Keane \& Crawley 2002). Alternatively, successful invasion might also be regulated by the competitive ability of NIS. In general, invasive success may be explained by 'the enemy release hypothesis' (Colautti et al. 2004) and by high competitive ability. NIS are characterised by their ability to adapt establish themselves in new environments and become successful competitors against native species. For example, between 1970 and 2000, the competitive dominant mussel, Mytilus galloprovincialis, aggressively invaded the rocky intertidal shore of South Africa. The species has spread rapidly, over thousands of kilometres, along sheltered and exposed rocky west and east shores of South Africa, displacing the mussels, Aulacomya ater and Choromytilus meridionalis (Griffiths et al. 1992, Collins et al. 1996, Robinson et al. 2007), and outcompeting the mid-intertidal limpet, Scutellastra argenvillei (Steffani \& Branch 2003a,b, 2005, Branch \& Steffani 2004).

Perumytilus purpuratus (Lamarck 1918) is a native mussel of South American rocky coasts and is distributed in coastal waters of the southeastern Pacific Ocean from Ecuador to the Strait of Magellan, and around Cape Horn into the South Atlantic as far north as La Lobería, Argentina (Bertness et al. 2006, Prado \& Castilla 2006). This species forms extensive and dense tridimensional beds in the mid-intertidal zone and is an important bioengineer species (Prado \& Castilla 2006). P. purpuratus is the dominant competitor for primary substrate in the mid-intertidal fringe of the rocky shores of north-central Chile, outcompeting other sessile species such as barnacles, algae and other mussel species (Castilla \& Durán 1985, Paine et al. 1985, Durán \& Castilla 1989, Guiñez \& Castilla 1999, Navarrete et al. 2005, Prado \& Castilla 2006).

Pyura praeputialis (Heller 1878) is a solitary tunicate that inhabits intertidal and shallow subtidal habitats, showing a conspicuous, disjointed geographical distribution (Castilla \& Guiñez 2000, Castilla et al. 2002). This tunicate inhabits wave-swept headlands on the southeastern shores of Australia, from where it appears to have originated (Fairweather 1991, Monteiro et al. 2002). This species is also found in northern Chile (Castilla et al. 2002), where it lives exclusively along approximately $70 \mathrm{~km}$ of rocky coast inside the Bay of Antofagasta $\left(23^{\circ} 38^{\prime} \mathrm{S}, 70^{\circ} 23^{\prime} \mathrm{W}\right.$, Fig. 1) (Guiller 1959, Paine \& Suchanek 1983, Underwood \& Fairweather 1986, Castilla 2008). Molecular evidence has demonstrated that $P$. praeputialis is a recent NIS invader to this bay, probably having arrived a few hundred years ago from Australia (Astorga et al. 2002, Castilla et al. 2002). In the rocky shore of the Bay of Antofagasta, P. praeputialis generates dense collective

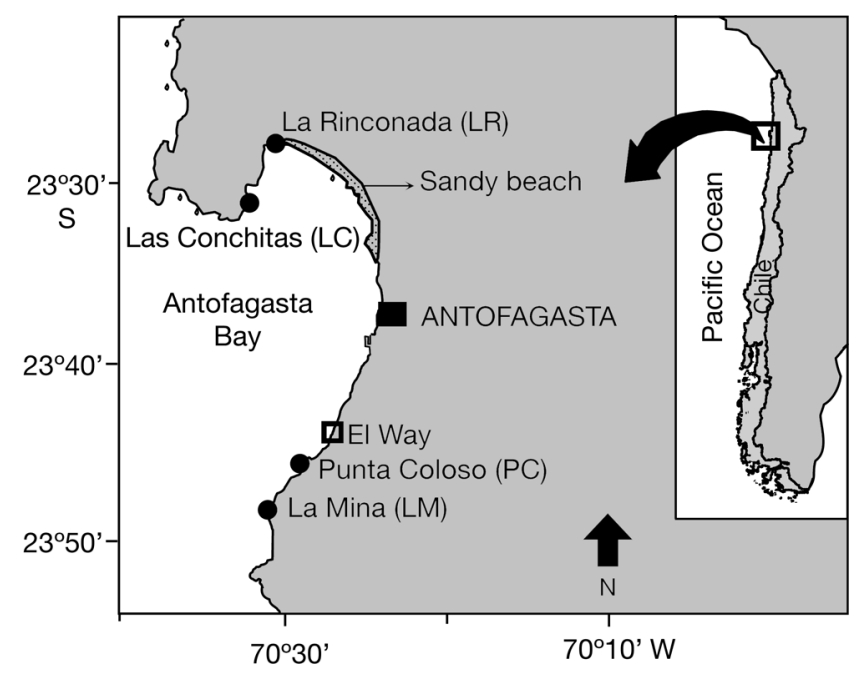

Fig. 1. Experimental sites ( $\bullet$ in the Bay of Antofagasta. Inset: study area in northern Chile

unities (pseudo-coloniality) forming extensive aggregations in the mid- and low-intertidal zones (Paine \& Suchanek 1983, Castilla et al. 2004, 2007).

In a previous study Castilla et al. (2004) showed that Pyura praeputialis is an aggressive interspecific competitor for primary space at the mid-low rocky intertidal fringe inside the Bay of Antofagasta. At this intertidal fringe the species appears to have the ability to overgrow the native mussel Perumytilus purpuratus. However, to date there are no experimental studies evaluating the strength of mussel-tunicate competition, thereby assessing the competitive performance of mussels and tunicates in the presence and absence of their competitors in the mid-low and mid-upper intertidal fringes. In this study, we use field experimental approaches to assess the interspecific competitive strength and physiological restrictions of both species at the mid-intertidal fringe. Hence, we attempt to deepen the understanding of the ecological processes determining the unique intertidal zonation pattern observed in the rocky shore of the Bay of Antofagasta. The aim of this work is to quantify growth, survival rates and the strength of competition between the native mussel $P$. purpuratus and the non-indigenous tunicate $P$. praeputialis, based on cross-transplants (alone and mixed treatments), at 4 different sites inside the Bay of Antofagasta within 2 intertidal subfringes: the mid-low intertidal fringe (M-LIF) where $P$. praeputialis dominates, and the mid-upper intertidal fringe (M-UIF) where P. purpuratus dominates. We hypothesized that at the M-UIF the mussel $P$. purpuratus is a stronger competitor than the tunicate $P$. praeputialis, while at the M-LIF P. praeputialis is a stronger competitor than P. purpuratus. 
A Frontal view

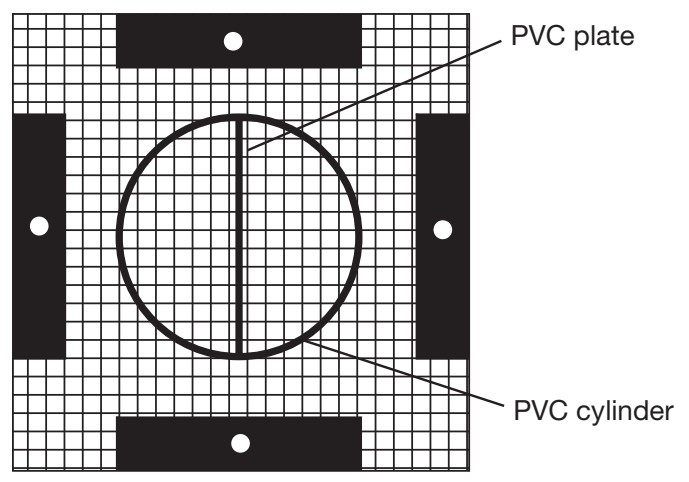

B Lateral view

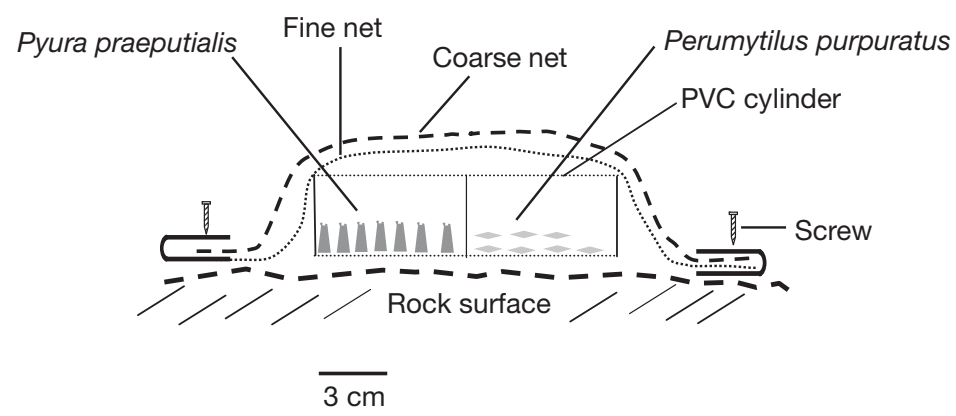

Fig. 2. (A) Frontal and (B) lateral views of cages used for tunicate-mussel competition experiments

\section{MATERIALS AND METHODS}

To evaluate the competitive interaction between the NIS tunicate Pyura praeputialis and the native mussel Perumytilus purpuratus in the Bay of Antofagasta, we transplanted juveniles of both species, using PVC cages installed at 2 tidal heights: the mid-low intertidal fringe and the mid-upper intertidal fringe (Castilla 1981, Castilla et al. 2004), where P. praeputialis and $P$. purpuratus, respectively, have higher densities (Castilla \& Camaño 2001). The experiments were carried out at 4 sites inside the Bay of Antofagasta: (1) La Mina (LM; $\left.23^{\circ} 48^{\prime} \mathrm{S}, 70^{\circ} 30^{\prime} \mathrm{W}\right)$, (2) Punta Coloso (PC; $\left.23^{\circ} 45^{\prime} \mathrm{S}, 70^{\circ} 27^{\prime} \mathrm{W}\right)$, (3) La Rinconada (LR; $23^{\circ} 27^{\prime} \mathrm{S}$, $70^{\circ} 30^{\prime} \mathrm{W}$ ) and (4) Las Conchitas (LC; $23^{\circ} 31^{\prime} \mathrm{S}$, $70^{\circ} 32^{\prime} \mathrm{W}$ ) (Fig. 1).

Juveniles of Pyura praeputialis between 13 to $17 \mathrm{~mm}$ in diameter and 19 to $24 \mathrm{~mm}$ maximum height were collected from El Way $\left(23^{\circ} 44^{\prime} \mathrm{S}, 70^{\circ} 26^{\prime} \mathrm{W}\right)$ (Fig. 1). In the laboratory, total wet mass, maximum height and maximum dorsal diameter were recorded for each tunicate. Perumytilus purpuratus juveniles of maximum length between 5 to $10 \mathrm{~mm}$ were collected from mussel beds at El Way. Before experiments began, to quantify shell growth, the left shell of each mussel was marked at the posterior growth border by means of a dentist drill (Guiñez \& Castilla 1999). Mussels and tunicates were maintained in running seawater $24 \mathrm{~h}$ before being transplanted to the field.

Cages were made from open PVC cylinders $10.7 \mathrm{~cm}$ in diameter and $4 \mathrm{~cm}$ high (surface area: $\sim 90 \mathrm{~cm}^{2}$; volume: $\sim 360 \mathrm{~cm}^{3}$ ). Cylinders were covered with 2 types of plastic nets: (1) a fine net $(20 \times 20 \mathrm{~cm}$, mesh aperture: $2 \mathrm{~mm})$ and (2) a coarse net $(20 \times 20 \mathrm{~cm}$, mesh aperture: $6 \mathrm{~mm}$ ) (Fig. 2). At the beginning of the experiment, animals were placed loosely in the cages covered with both nets. After $\sim 1$ mo individuals had attached to the substrate either through byssus threads (Perumytilus purpuratus) or tunic production (Pyura praeputialis). The fine net facilitated the adhering processes, reducing hydrodynamic forces within the cages and was removed in the second month. The coarse net prevented predators from entering the cages and was maintained throughout the experiment. Since $P$. praeputialis and P. purpuratus juveniles have different sizes and forms, to standardize the intra- and interspecific competition to the same biomass by unit surface area, we kept a constant biomass $(20 \pm 2 \mathrm{~g})$ by cage area. Three competition treatments were carried out: (1) Treatment A: 10 $P$. praeputialis $(10 \mathrm{~g})$ were randomly mixed with $20 P$. purpuratus individuals $(10 \mathrm{~g}),(2)$ Treatment B: $10 P$. praeputialis $(10 \mathrm{~g})$ were randomly placed alone, (3) Treatment C: 20 P. purpuratus (10 g) were randomly placed alone. In Treatment $\mathrm{A}$, the full cage volume was used; while, in Treatments B and C, the experimental cage was divided in 2 halves (surface area: $\sim 45 \mathrm{~cm}^{2}$; volume: $\sim 180 \mathrm{~cm}^{3}$; Fig. 2) by means of a PVC plate. In the latter treatments, 1 of the halves, determined at random, was used for experimentation and the other remained empty. A set of 3 cages (1 per treatment) was arranged as a plot, and cages were attached to the intertidal rocks with stainless steel screws (Fig. 2). For each combination of site and tidal heights 5 replicate plots were randomly assigned. Experiments ran from 11-15 July to 19-21 December 1999. The nets covering the cages were cleaned of epibionts at least once a month and predator presence or absence on the experimental units was verified.

At the end of the experiment we determined (1) the number of individual Pyura praeputialis and Perumytilus purpuratus alive, and (2) $P$. praeputialis and 
P. purpuratus growth. For P. praeputialis, the initial dry viscera mass for each individual was estimated by means of a nonlinear equation: dry viscera mass $=6.7 \times$ $10^{-5} \times$ (diameter) $^{2.448}$, (see Eq. 2 in Castilla et al. 2004). The initial total dry mass was estimated with the linear equation: total dry mass $=0.160+0.286 \times$ wet mass (see Eq. 1 in Castilla et al. 2004). The initial tunic dry mass was estimated as the difference of initial total dry mass minus initial visceral dry mass. Final dry masses were determined in grams with a digital balance (accuracy: $\pm 0.001 \mathrm{~g}_{1}$ ) after drying the respective tissues in an oven at $70^{\circ} \mathrm{C}$ for $72 \mathrm{~h}$. The growth rate of $P$. purpuratus was determined as the increment in shell size and was quantified as the distance between the initial drill mark and the new border of the shell. After the experimental units were removed from the field and brought to the laboratory, we used digital photography to determine the degree to which $P$. praeputialis had encroached (i.e. overgrown) $P$. purpuratus inside the cylinders. This procedure was applied only to those experimental units containing both species. The criteria to estimate $P$. praeputialis encroachment was the percentage of mussel shells covered by the tunicates (from a frontal view of the experimental unit) according to the following scale: (1) total encroachment: $>80 \%$; (2) partial encroachment: $\leq 80 \%$ and $\geq 20 \%$;

(3) no encroachment: $<20 \%$ of shells covered.

For each species we performed a 3-way mixed analysis of covariance (ANCOVA) with 'Site' as a random factor and 'Treatment' and 'Tidal height' as fixed effects. For both species we used survival as the dependent variable and initial dry biomass as a covariate. For Perumytilus purpuratus, we used differential shell growth (final length minus initial shell maximum length) as the dependent variable. For Pyura praeputialis, we used differential mean tunic mass and visceral dry tissue growth as dependent variables, and survival number as a covariate. We also conducted a 3-way blocked ANOVA (factors were: Site, Tidal height, Degree of encroachment) for mussel growth, with Site as a random blocking factor. For statistical analyses we used PROC GLM (SAS 2002). When interaction terms in factorial designs were significant we compared cell means using the SLICE option in PROC GLM (SAS 2002). We estimated the intensity of interspecific competition (Lotka \& Volterra competitive coefficients) separately at both intertidal heights, estimated as the per capita effect on ratio between the initial and final survival during the 5 mo of the experiment. To estimate this coefficient, we fitted linear regressions of the ratios between the initial and final survival of the focal species (in logarithmic scale) versus time. The slope of this regression is an estimator of the interspecific competition coefficient among transplanted individuals at each site.

\section{RESULTS}

Pyura praeputialis survival varied with competition treatment and tidal height (Treatment $\times$ Tidal height interaction, $p=0.050$; Table 1A, Fig. 3A,B), but did not vary with Site and other Site interactions (Table 1). In the M-LIF P. praeputialis survival was not affected by the presence of Perumytilus purpuratus $(\mathrm{p}=0.432$;

Table 1. Pyura praeputialis. (A) Three-way (Site, Tidal height and Treatment) mixed ANCOVA for survival. The covariate was the initial biomass. (B) Treatment $\times$ Tidal height effect sliced by Tidal height (see 'Materials and methods'; SAS 2002). p-values in bold text are significant ( $p<0.05)$

\begin{tabular}{|c|c|c|c|c|}
\hline $\begin{array}{l}\text { A) 3-way ANCOVA } \\
\text { Source of variation }\end{array}$ & df & MS & $F$ & $\mathrm{p}$ \\
\hline Covariate & 1 & 5.8378 & 1.38 & 0.244 \\
\hline Site & 3 & 11.0009 & 0.58 & 0.655 \\
\hline Tidal height & 1 & 386.8427 & 32.54 & 0.010 \\
\hline Treatment & 1 & 8.0207 & 0.88 & 0.419 \\
\hline Site $\times$ Tidal height & 3 & 11.9952 & 4.73 & 0.097 \\
\hline Site $\times$ Treatment & 3 & 9.0791 & 3.72 & 0.158 \\
\hline Treatment $\times$ Tidal height & 1 & 22.3499 & 8.86 & 0.050 \\
\hline Treat $\times$ Site $\times$ Tidal height & it 3 & 2.4535 & 0.58 & 0.629 \\
\hline Error & 63 & 4.2184 & & \\
\hline \multicolumn{5}{|c|}{ B) Treatment $\times$ Tidal height effect sliced by Tidal height } \\
\hline Tidal height $\quad$ df & SS & MS & $F$ & $\mathrm{p}$ \\
\hline M-LIF & 2.0119 & 2.0119 & 0.82 & 0.432 \\
\hline M-UIF & 28.8933 & 28.8933 & 11.78 & 0.042 \\
\hline
\end{tabular}

Table 2. Pyura praeputialis. (A) Three-way (Site, Tidal height and Treatment) mixed ANCOVA for growth: dry viscera mass (final minus initial). The Site $\times$ Tidal height $\times$ Treatment interaction was used as an error term. Survival as a covariate was not significant $\left(F_{1,36}=0.62, \mathrm{p}=0.43\right)$. (B) Site $\times$ Treatment effect sliced by Site (see 'Materials and methods'; SAS 2002). p-values in bold text are significant ( $p<$ $0.05)$

\begin{tabular}{|c|c|c|c|c|}
\hline $\begin{array}{l}\text { A) 3-way ANCOVA } \\
\text { Source of variation }\end{array}$ & $\mathrm{df}$ & MS & $F$ & $\mathrm{P}$ \\
\hline Site & 3 & 0.0028 & 1.09 & 0.452 \\
\hline Tidal height & 1 & 0.0111 & 17.16 & 0.014 \\
\hline Treatment & 1 & 0.0048 & 2.26 & 0.219 \\
\hline Site $\times$ Tidal height & 3 & 0.0007 & 1.38 & 0.265 \\
\hline Site $\times$ Treatment & 3 & 0.0028 & 5.62 & 0.003 \\
\hline Treatment $\times$ Tidal height & 1 & 0.0005 & 0.92 & 0.344 \\
\hline Error & 37 & 0.0005 & & \\
\hline \multicolumn{5}{|c|}{ B) Site $\times$ Treatment effect sliced by Site } \\
\hline Site $\quad$ df & SS & MS & $F$ & $\mathrm{p}$ \\
\hline La Mina & 0.0017 & 0.0017 & 3.34 & 0.076 \\
\hline Punta Coloso & 0.0032 & 0.0032 & 6.43 & 0.016 \\
\hline La Rinconada & 0.0012 & 0.0012 & 2.42 & 0.129 \\
\hline Las Conchitas & 0.0055 & 0.0055 & 11.00 & 0.002 \\
\hline
\end{tabular}


Table 1B, Fig. 3A), but in the M-UIF its survival was lower in the presence than in the absence of $P$. purpuratus $(\mathrm{p}=0.042$; Table 1B, Fig. 3B). At this tidal height, $P$. praeputialis survival in Treatment A (both species mixed) decreased by about $75 \%$ compared with Treatment B ( $P$. praeputialis alone; Fig. 3B).

Pyura praeputialis tunic dry mass (ANCOVA: $F_{1,3}=19.82, \mathrm{p}=0.001$; Fig. $3 C, D)$ and viscera dry mass tissues $(p=0.014$; Table 2A, Fig. $3 E, F)$, grew more slowly at the M-UIF than at the M-LIF. At both tidal heights, tunic growth was faster in the P. praeputialis alone treatment than in the competition treatment (Treatment A), but this effect was not significant (ANCOVA: $F_{1,3}=1.98, \mathrm{p}=0.214$; Fig. $3 C, D)$. Visceral tissue growth varied with site and competition $(p=$ 0.003; Table 2A, Fig. 3E,F). This interaction reflects the negative effect of Perumytilus purpuratus on $P$. praeputialis visceral tissue growth at Punta Coloso and Las Conchitas $(p=0.016$ and $\mathrm{p}=0.002$, respectively; Table $2 \mathrm{~B}$, Fig. 3E,F). Only marginal effects were observed at La Mina ( $p=0.076$; Table 2B, Fig. 3E,F) and no effect was observed at La Rinconada ( $p=0.129$; Table 2B, Fig. 3E,F).

Survival of the mussel Perumytilus purpuratus was not affected by the presence of Pyura praeputialis individuals (ANOVA: $F_{1,3}=0.52, \mathrm{p}=$ 0.522 ; Fig. 4A,B). Mussel growth, however, varied with both tidal height and the presence of the tunicate. $P$. purpuratus grew faster at the M-LIF (i.e. in the centre of the $P$. praeputialis belt, $\mathrm{p}=0.006$; Table 3, Fig. 4C,D) than at the M-UIF (i.e. in the centre of $P$. purpuratus belt), and even faster in the mixed treatment with $P$. praeputialis, than alone $(\mathrm{p}=0.025$; Table 3 , Fig. 4C,D). Nevertheless, when the competition treatment was analyzed according to the degree of encroachment of $P$. praeputialis on $P$. purpuratus, as encroachment increased the growth of $P$. purpuratus decreased ( $p<0.001$; Table 4A, Fig. 5). The encroaching effect of $P$. praeputialis on $P$. purpuratus was more important at the M-LIF than at the M-UIF $\left(F_{2,95}=\right.$ 239.80 and $F_{2,95}=50.15$, respectively; Table 4B, Fig. 5).
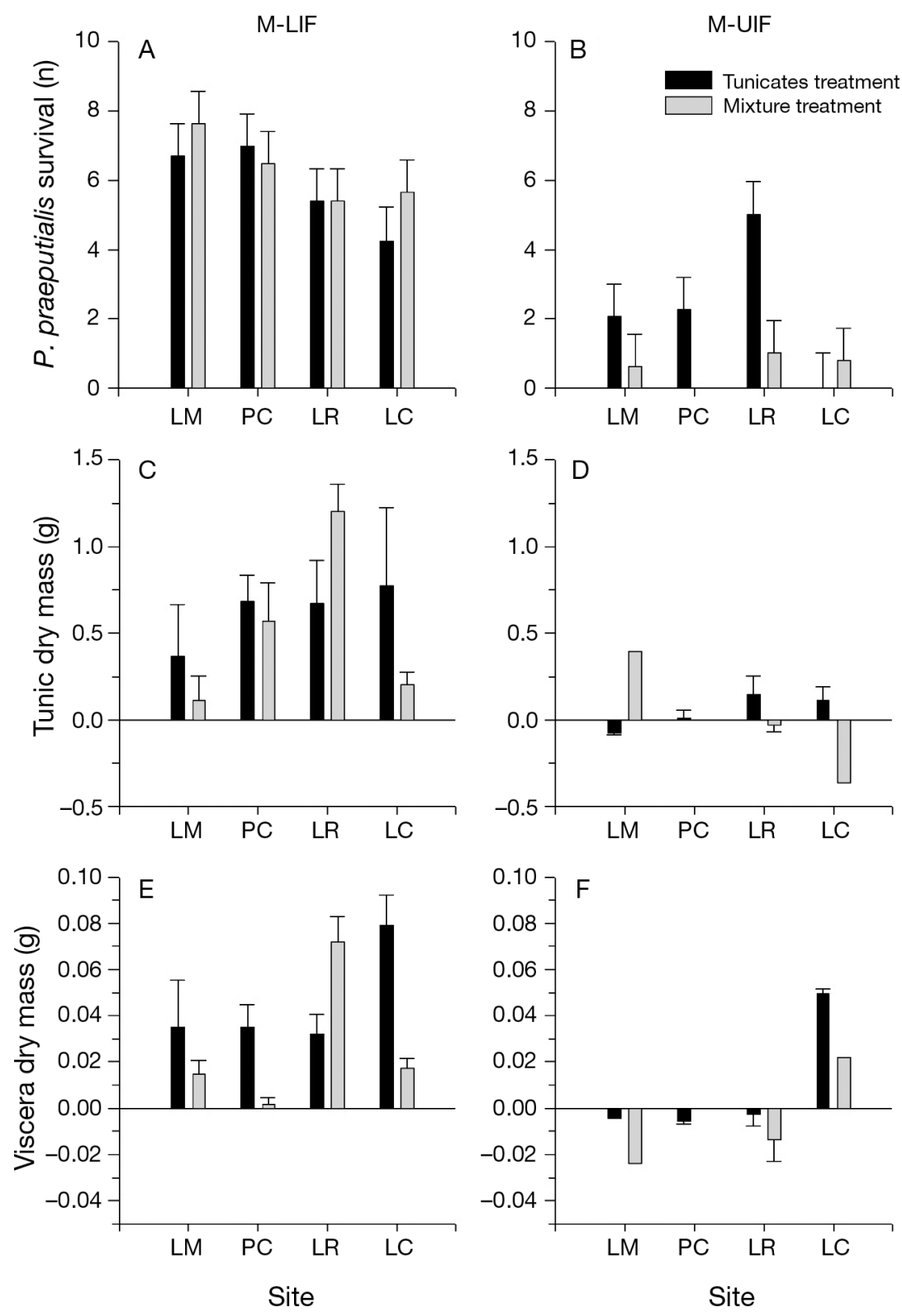

Fig. 3. Pyura praeputialis. Survival and growth under 2 competition treatments. Tunicates treatment (black bars) and Mixture treatment (grey bars) at 4 sites and 2 intertidal fringes: mid-low intertidal fringe (M-LIF: $A, C, E)$ and mid-upper intertidal fringe (M-UIF: $B, D, F)$. (A,B) Survival, $(C, D)$ dry tunic mass, $(\mathrm{E}, \mathrm{F})$ dry visceral mass. Means +1 SE for 4 independent experimental units. LM: La Mina; PC: Punta Coloso; LR: La Rinconada; LC: Las Conchitas (for locations see Fig. 1)

The interspecific competition coefficients of Pyura praeputialis on Perumytilus purpuratus differed between tidal heights ( $\mathrm{p}=0.03$; Fig. 6). P. praeputialis had a higher competitive performance in the mid-low intertidal fringe (Fig. 6), while in the mid-upper intertidal fringe its competitive performance decreased. $P$. purpuratus had a low competitive intensity at both intertidal heights (Fig. 6). 

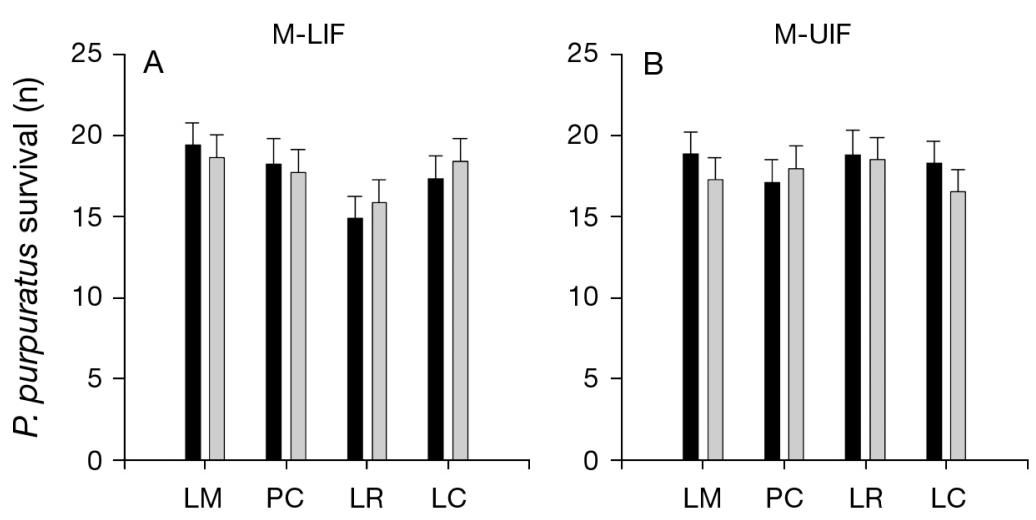

Young (1992) on the suspected competition between the ascidian Eudistoma capsulatum and the oyster Ostrea equestris where ascidians overgrowing oysters had no effect on the final oyster size, but in 2 ascidia-oyster matrix experiments the final oyster size was enhanced. A previous study (Castilla et al. 2004) performed on the $P$. praeputialis-P. purpuratus interaction showed that $P$. purpuratus matrices transplanted to the M-LIF and in contact with natural beds of $P$. praeputialis, were systematically overgrown (encroached) by the tunicates. Those previous findings and our present results, based on experimental transplants of $P$. praeputialis juveniles, reinforce the hypothesis that since its arrival to the Bay of Antofagasta $P$. praeputialis have outcompeted $P$. purpuratus at the M-LIF.

Further, the present results show that Pyura praeputialis grew faster (tunic and viscera) at the M-LIF than at the M-UIF (Fig. 3C-F), suggesting that environmental conditions are more favorable for the tunicate at the M-LIF, but worse at the M-IUF. Therefore, our results are consistent with the suggestions made by Paine \& Suchanek (1983) that the abrupt upper intertidal limit of this tunicate would

\section{DISCUSSION}

Our experiment demonstrated that at the M-LIF the non-indigenous tunicate Pyura praeputialis was a stronger competitor than the native mussel Perumytilus purpuratus. However, at the M-UIF the competitive ability of the tunicate was reduced. The survival of $P$. praeputialis at the M-LIF was not reduced by the presence of $P$. purpuratus (Fig. 3A). Nevertheless, tunicate survival was reduced in the mixed treatment at the M-UIF (where P. purpuratus dominates; Fig. 3B), while $P$. purpuratus survival was not affected by competition with $P$. praeputialis (Fig. 4A,B). Overall, the mussels grew faster when mixed with $P$. praeputialis than when grown alone (Table 3, Fig. 4C,D). This may be due to greater moisture retention in mixed than in non-mixed units, thereby reducing physiological stress for P. purpuratus. Nevertheless, at both tidal heights, $P$. purpuratus individuals that were totally or partially encroached by $P$. praeputialis inside the cages, grew less than the non-encroached ones (Table 4, Fig. 5). These results differ from those reported by Dalby \& be related to physiological stress and would not be the result of biological interactions. On the other hand, the mussel Perumytilus purpuratus grew faster at the M-LIF than at the M-UIF. Increased growth rates for the mussel in low intertidal and even shallow subtidal habitats, compared with those in mid-intertidal habi-

Table 3. Perumytilus purpuratus. Three-way (Site, Tidal height and Treatment) mixed ANCOVA for differential shell growth (final minus initial). The covariate was survival number. $\mathrm{p}$-values in bold text are significant $(\mathrm{p}<0.05)$

\begin{tabular}{|lrrrc|}
\hline Source of variation & df & MS & \multicolumn{1}{c|}{$F$} & $\mathrm{p}$ \\
\hline Covariate & 1 & 3.2984 & 5.77 & 0.019 \\
Site & 3 & 1.5454 & 0.92 & 0.558 \\
Tidal height & 1 & 87.2487 & 50.51 & $\mathbf{0 . 0 0 6}$ \\
Treatment & 1 & 13.6821 & 17.49 & $\mathbf{0 . 0 2 5}$ \\
Site $\times$ Tidal height & 3 & 1.6895 & 2.10 & 0.274 \\
Site $\times$ Treatment & 3 & 0.7819 & 0.96 & 0.512 \\
Treatment $\times$ Tidal height & 1 & 1.4728 & 1.82 & 0.270 \\
Treat $\times$ Site $\times$ Tide height & 3 & 0.8110 & 1.42 & 0.246 \\
Error & 61 & 0.5719 & & \\
\hline
\end{tabular}


Table 4. Perumytilus purpuratus. (A) Three-way (Site, Tidal height and Scale of encroaching) mixed ANOVA for differential shell growth (final minus initial). (B) Tidal height $\times$ Scale of encroaching effect sliced by Tidal height. $p$-values in bold text are significant $(p<0.05)$

\begin{tabular}{|c|c|c|c|c|}
\hline $\begin{array}{l}\text { A) 3-way ANOVA } \\
\text { Source of variation }\end{array}$ & df & MS & $F$ & $\mathrm{p}$ \\
\hline Site & 3 & 0.4644 & 1.64 & 0.185 \\
\hline Tidal height & 1 & 260.9348 & 921.24 & $<0.001$ \\
\hline Scale of encroaching & 2 & 71.0068 & 250.69 & $<0.001$ \\
\hline Site $\times$ Tidal Height & 3 & 1.4237 & 5.03 & 0.003 \\
\hline Site $\times$ Scale of encroaching & 6 & 0.2872 & 1.01 & 0.421 \\
\hline $\begin{array}{l}\text { Tidal height } \times \text { Scale of } \\
\text { encroaching }\end{array}$ & 2 & 11.8192 & 41.73 & $<0.001$ \\
\hline $\begin{array}{l}\text { Site } \times \text { Tidal height } \times \text { Scale } \\
\text { of encroaching }\end{array}$ & 6 & 0.1497 & 0.53 & 0.785 \\
\hline Error & & & 95 & 0.2832 \\
\hline \multicolumn{5}{|c|}{ B) Tidal height $\times$ Scale of encroaching effect sliced by Tidal height } \\
\hline Tidal height $\quad$ df & SS & MS & F & $\mathrm{p}$ \\
\hline M-LIF & 135.8612 & 67.9306 & 239.80 & $<0.001$ \\
\hline M-UIF & 28.4094 & 14.2047 & 50.15 & $<0.001$ \\
\hline
\end{tabular}

(1) Many of such cases may not exist. It is possible, for example, that ecologically drastic alterations, such as modifications in intertidal zonation, may be rare owing to negative biotic interactions with native species and/or to abiotic factors preventing rocky shore invasive species from becoming established (Reusch \& Williams 1999). (2) Major inshore ecological modifications exist but have not been properly documented (but see Crooks \& Khim 1999, Steffani \& Branch 2005). (3) There is a lack of experimental approaches (but see Troost 2010) since most reported studies are descriptive (for example see Griffiths et al. 1992, Vermeij 1996, Orensanz et al. 2002). Undoubtedly, more field experimental approaches and manipulations, such as that presented here, are needed to fully understand the consequences of interactions between native and invasive species in coastal marine environments. tats (where they normally live), have been also reported in central Chile (Cancino \& Rojas 1986). Hence, our results suggest that environmental conditions are generally better for both species at the M-LIF than the M-UIF, but also that the tunicate is the competitive dominant species lower on the shore and, via competitive effects, restricts the mussel beds to the upper shore where the tunicate can not tolerate the environmental conditions. This supports the hypothesis that in the Bay of Antofagasta the invasive tunicate $P$. praeputialis has had a major ecological impact, outcompeting the native mussel $P$. purpuratus from the M-LIF. The estimated competition coefficients show that $P$. praeputialis gains in competition to $P$. purpuratus at the M-LIF and dominates this intertidal fringe (Fig. 6). The experimental and analytical procedures used in this study allow us to compare the intensity of interspecific competition with other competitive interactions in nature.

So far, the experimental ecology of marine, non-indigenous, competitively dominant invertebrate species, which can potentially cause major ecological modifications to inshore systems, has received little attention in the literature (but see Crooks 2002, Rilov \& Crooks 2009). This may be due to a number of reasons.
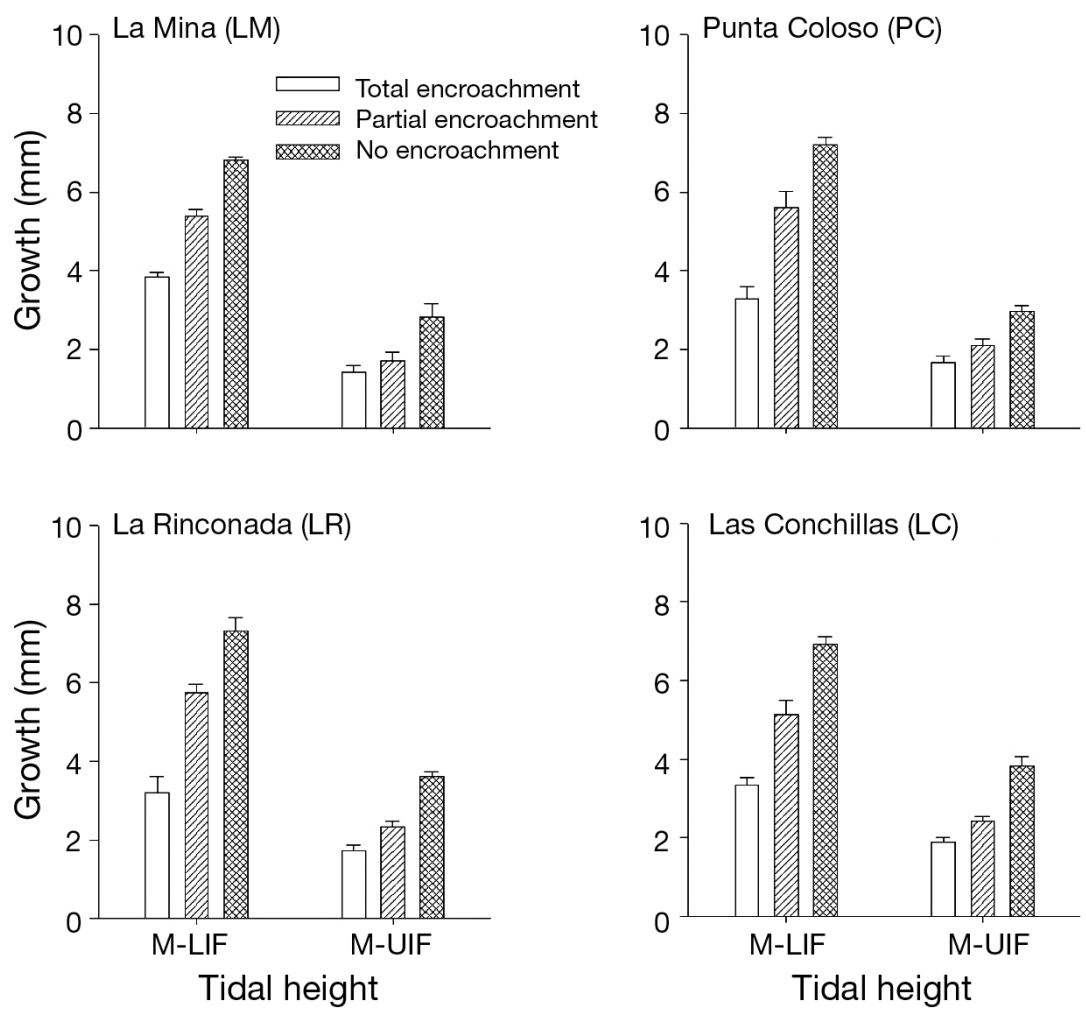

Fig. 5. Perumytilus purpuratus. Shell growth under 3 degrees of Pyura praeputialis encroachment at 4 sites and 2 intertidal fringes: M-LIF and M-UIF. The following degree of encroachment was used, according to the percentage of individual mussel shells covered by P. praeputialis: $>80 \%=$ total encroachment $(\square) ; \leq 80 \%$ to $\geq 20 \%=$ partial encroachment (源); $<20 \%=$ no encroachment ( $)$. For abbreviations see Fig. 3 


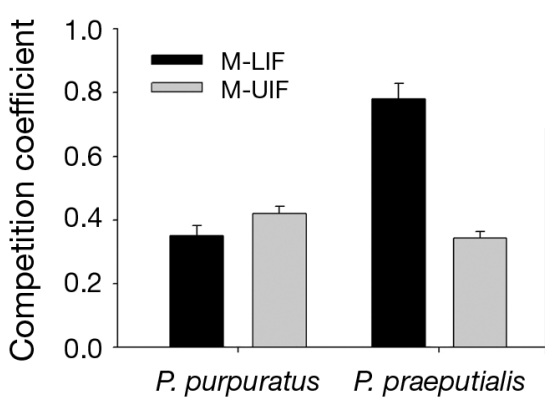

Fig. 6. Interspecific competition coefficients for the native mussel Perumytilus purpuratus and the invader tunicate Pyura praeputialis at 2 intertidal heights: mid-low intertidal fringe (M-LIF) and mid-upper intertidal fringe (M-UIF)

Acknowledgements. We acknowledge financial support from the Mellon Foundation-Pontificia Universidad (PU) Católica de Chile grant to S. Navarrete and J.C.C. and the Center for Advanced Studies in Ecology and Biodiversity (CONICYT FONDAP Project 1501-0001), Facultad de Ciencias, Biológicas, PU Católica de Chile. We also acknowledge the logistic support provided by the Universidad de Antofagasta, Facultad de Recursos del Mar. We sincerely thank M. Clarke, M. Uribe, R. Pinto, J. Alvarado, C. Pacheco, M. Cerda, M. Varas, A. Delgado and L. Figueroa for field and laboratory assistance. S. Navarrete, P. Neill, B. Kelaher and 3 anonymous referees suggested important modifications to previous versions of this manuscript.

\section{LITERATURE CITED}

Astorga M, Guiñez R, Ortiz JC, Castilla JC (2002) Phenotypic and genetic variation in tunicate Pyura praeputialis (Heller, 1878) in the northern sac of the Antofagasta Bay. Rev Chil Hist Nat 75:515-526

Bertness MD, Crain CM, Silliman BR, Bazterrica MC, Reyna MV, Hildago F, Farina JK (2006) The community structure of western Atlantic Patagonian rocky shores. Ecol Monogr 76:439-460

Branch GM, Steffani CN (2004) Can we predict the effects of alien species? A case-history of the invasion of South Africa by Mytilus galloprovincialis (Lamarck). J Exp Mar Biol Ecol 300:189-215

Bubb DH, Thom TJ, Lucas MC (2006) Movement, dispersal and refuge use of co-occurring introduced and native crayfish. Freshw Biol 51:1359-1368

Cancino J, Rojas M (1986) Evaluación del potencial de crecimiento de Perumytilus purpuratus a distintas alturas en el intermareal de Chile central. Medio Ambiente 8:27-32

Castilla JC (1981) Perspectivas de investigación en enstructura y dinámica de comunidades intermareales rocosas de Chile Central. II. Depredadores de alto nivel tráfico. Medio Ambiente 5:190-215

Castilla JC (2008) Fifty years from the publication of the first two papers on Chilean rocky intertidal assemblages: honoring Professor Eric R. Guiler. Rev Biol Mar Oceanogr 43: 457-467

Castilla JC, Camaño A (2001) El piure de Antofagasta, Pyura praeputialis (Heller, 1878): un competidor dominante e ingeniero de ecosistemas. In: Alveal K, Antezana T (eds) Sustentabilidad de la biodiversidad. Universidad de Concepción, Concepción, p 719-729
Castilla JC, Durán LR (1985) Human exclusion from the rocky intertidal zone of central of central Chile: the effects on Concholepas concholepas (Gastropoda). Oikos 45: 391-399

Castilla JC, Guiñez R (2000) Disjoint geographical distribution of intertidal and nearshore benthic invertebrates in the Southern Hemisphere. Rev Chil Hist Nat 73:585-603

Castilla JC, Collins AG, Meyer CP, Guiñez R, Lindberg DR (2002) Recent introduction of the dominant tunicate, Pyura praeputialis (Urochordata, Pyuridae) to Antofagasta, Chile. Mol Ecol 11:1579-1584

Castilla JC, Guiñez R, Caro AU, Ortiz V (2004) Invasion of a rocky intertidal shore by the tunicate Pyura praeputialis in the Bay of Antofagasta, Chile. Proc Natl Acad Sci USA 101:8517-8524

Castilla JC, Manriquez PH, Delgado AP, Gargallo L, Leiva A, Radic D (2007) Bio-foam enhances larval retention in a free-spawning marine tunicate. Proc Natl Acad Sci USA 104:18120-18122

Colautti RI, Ricciardi A, Grigorovich IA, MacIsaac HJ (2004) Is invasion success explained by the enemy release hypothesis? Ecol Lett 7:721-733

Collins TM, Frazer K, Palmer R, Vermeij GJ, Brown WM (1996) Evolutionary history of Northern Hemisphere Nucella (Gastropoda, Muricidae): molecular, morphological, ecological, and paleontological evidence. Evolution 50:2287-2304

Crooks JA (2002) Characterizing ecosystem-level consequences of biological invasions: the role of ecosystem engineers. Oikos 97:153-166

Crooks JA, Khim HS (1999) Architectural vs. biological effects of a habitat-altering, exotic mussel, Musculista senhousia. J Exp Mar Biol Ecol 240:53-75

> Dalby JE, Young CM (1992) Role of early postsettlement mortality in setting the upper depth limit of ascidians in Florida epifaunal communities. Mar Ecol Prog Ser 80: 221-228

> Durán LR, Castilla JC (1989) Variation and persistence of the middle rocky intertidal community of central Chile, with and without human harvesting. Mar Biol 103:555-562

Eastwood MM, Donahue MJ, Fowler AE (2007) Reconstructing past biological invasions: niche shifts in response to invasive predators and competitors. Biol Invasions 9: 397-407

Fairweather PG (1991) A conceptual framework for ecological studies of coastal resources: an example of a tunicate collected for bait on Australian seashores. Ocean Coast Manag 15:125-142

Fridley JD, Stachowicz JJ, Naeem S, Sax DF and others (2007) The invasion paradox: reconciling pattern and process in species invasions. Ecology 88:3-17

Griffiths CL, Hockey PAR, Schurink CV, Le Roux PJ (1992) Marine invasive aliens on South African shores: implications for community structure and trophic functioning. S Afr J Mar Sci 12:713-722

Grosholz E (2002) Ecological and evolutionary consequences of coastal invasions. Trends Ecol Evol 17:22-27

Guiller ER (1959) Intertidal belt-forming species on the rocky coasts of Northern Chile. Pap Proc R Soc Tasman 93:33-58

Guiñez R, Castilla JC (1999) A tridimensional self-thinning model for multilayered intertidal mussels. Am Nat 154: 341-357

Holway DA, Lach L, Suarez AV, Tsutsui ND, Case TJ (2002) The causes and consequences of ant invasions. Annu Rev Ecol Syst 33:181-233

> Keane RM, Crawley MJ (2002) Exotic plant invasions and the enemy release hypothesis. Trends Ecol Evol 17:164-170 
Kolar CS, Lodge DM (2001) Progress in invasion biology: predicting invaders. Trends Ecol Evol 16:199-204

Kolar CS, Lodge DM (2002) Ecological predictions and risk assessment for alien fishes in North America. Science 298: 1233-1236

Lambert WJ, Levin PS, Berman J (1992) Changes in the structure of a New England (USA) kelp bed: the effects of an introduced species? Mar Ecol Prog Ser 88:303-307

Monteiro SM, Chapman MG, Underwood AJ (2002) Patches of the ascidian Pyura stolonifera (Heller, 1878): structure of habitat and associated intertidal assemblages. J Exp Mar Biol Ecol 270:171-189

- Navarrete SA, Wieters EA, Broitman BR, Castilla JC (2005) Scales of benthic-pelagic and the intensity of species interactions: from recruitment limitation to top-down control. Proc Natl Acad Sci USA 102:18046-18051

Olyarnik SV, Bracken MES, Byrnes JE, Hughes AR, Hultgren KM, Stachowicz JJ (2009) Ecological factors affecting community invasibility. In: Rilov G, Crooks JA (eds) Biological invasions in marine ecosystems: ecological, management, and geographic perspectives. Ecological Studies 204. Springer, Berlin, p 215-239

Orensanz JM, Schwindt E, Pastorino G, Bortolus A and others (2002) No longer a pristine confine of the world ocean: a survey of exotic marine species in the southwestern Atlantic. Biol Invasions 4:115-143

Paine RT, Suchanek TH (1983) Convergence of ecological processes between independently evolved competitive dominants: a tunicate-mussel comparison. Evolution 37: 821-831

Paine RT, Castilla JC, Cancino J (1985) Perturbation and recovery patterns of starfish-dominated intertidal assemblages in Chile, New Zealand, and Washington State. Am Nat 125:679-691

Prado L, Castilla AC (2006) The bioengineer Perumytilus purpuratus (Mollusca: Bivalvia) in central Chile: biodiversity, habitat structural complexity and environmental heterogeneity. J Mar Biol Assoc UK 86:417-421

Reusch TBH, Williams SL (1999) Macrophyte canopy structure and the success of an invasive marine bivalve. Oikos

Editorial responsibility: Roger Hughes, Bangor, UK
84:398-416

Rilov G, Crooks JA (eds) (2009) Biological invasions in marine ecosystems: ecological, management, and geographic perspectives. Ecological Studies 204. Springer, Berlin

> Robinson TB, Branch GM, Griffiths CL, Govender A, Hockey PAR (2007) Changes in South African rocky intertidal invertebrate community structure associated with the invasion of the mussel Mytilus galloprovincialis. Mar Ecol Prog Ser 340:163-171

Ruiz GM, Carlton JT, Grosholz ED, Hines AH (1997) Global invasions of marine and estuarine habitats by non-indigenous species: mechanisms, extent, and consequences. Am Zool 37:621-632

Ruiz GM, Fofonoff PW, Carlton JT, Wonham MJ, Hines AH (2000) Invasion of coastal marine communities in North America: apparent patterns, processes, and biases. Annu Rev Ecol Syst 31:481-531

SAS (2002) The SAS ${ }^{\circledR}$ system for Windows v. 9.0. SAS Institute, Cary, NC

> Steffani CN, Branch GM (2003a) Spatial comparisons of populations of an indigenous limpet Scutellastra argenvillei and an alien mussel Mytilus galloprovincialis along a gradient of wave energy. S Afr J Mar Sci 25:195-212

Steffani CN, Branch GM (2003b) Temporal changes in an interaction between an indigenous limpet Scutellastra argenvillei and an alien mussel Mytilus galloprovincialis: effects of wave exposure. S Afr J Mar Sci 25:213-229

Steffani CN, Branch GM (2005) Mechanisms and consequences of competition between an alien mussel, Mytilus galloprovincialis, and an indigenous limpet, Scutellastra argenvillei. J Exp Mar Biol Ecol 317:127-142

> Troost K (2010) Causes and effects of a highly successful marine invasion: case-study of the introduced Pacific oyster Crassostrea gigas in continental NW European estuaries. J Sea Res 64:145-165

Underwood AJ, Fairweather PG (1986) Intertidal communities: Do they have different ecologies or different ecologists? Proc Ecol Soc Aust 14:7-16

> Vermeij GJ (1996) An agenda for invasion biology. Biol Conserv 78:3-9

Submitted: August 21, 2010; Accepted: January 31, 2011

Proofs received from author(s): April 20, 2011 